\title{
The Corporeality of Silence: Dispossession of Person-and-Selfhood in Yvonne Vera's Butterfly Burning (2000)
}

\section{Abib SENE*}

Cheikh Anta Diop University Faculty of Arts and Social Sciences Laboratory of African and Postcolonial Studies

*Corresponding author: Abib SENE

\section{Abstract}

Set in a context of colonization, Butterfly Burning is a fictional work that digs out the colonized's mind to illustrate the brutality and unfairness of a ruthless system that gangrenes a whole community's reason of existence. This paper which finds ground on the theory of "the paradox of silence" as it is defined by Maurice Zundel, highlights a reflexion based on the social and political meaning of the praxis of silence among men and women who are deprived of the backbone of their raison d'être. It focuses on the built-in meaning attached to framework, sex and music in an ambient world silenced by the readable and audible voice of voicelessness.

Keywords: colonization, silence, corporeality, exploitation, sex, women, men.

Copyright @ 2020: This is an open-access article distributed under the terms of the Creative Commons Attribution license which permits unrestricted use, distribution, and reproduction in any medium for non-commercial use (NonCommercial, or CC-BY-NC) provided the original author and source are credited.

\section{INTRODUCTION}

Based on colonial Zimbabwe, Butterfly Burning is a novel that stresses on the incapacitation of men and women in the Rhodesian region in the 1940's. It browses through the book of the natives' history to come up with the audible silence that went hand in glove with the unhuman and inhumane exploitation of indigenous populations in days of colonization. In so being, Yvonne Vera, as a female writer, revisits the female and male worlds to problematize the notion of corporate silence. Through the notions of Personhood and Selfhood which can be understood as exact reflections of the status of being a human being with an individual and centred identity, the issue of silence is to be articulated and highlighted athwart the enigma of loquacious muteness.

Indeed, defined in the Oxford Learner's Dictionary as "an occasion when nobody speaks, although people are aware that there are feelings or thoughts to express", silence is a praxis thematized in Butterfly Burning to put on surface "the personae" [1] of the local population who, definitely, bear the mask of muteness to speak out their inner selves. In a context in which the colonized and the colonizer shape a relationship based on mutual rejection and reciprocal hate, the right and power to vocalize one's mind becomes a challenging issue, of which control or loss of control humanizes and empowers or dehumanizes and disempowers a community. Rhodesia was a case in point. And Vera fully portrays the image of a butterfly whose wings burn to raise a thousand and one questions: Why, in Butterfly Burning, are Zimbabwean natives in-grouped into a stand to silence? How do they use silence as an efficient means of communication? How does Kwela music and sex constitute loudspeakers of the colonized's mind? In a perspective to find the answers of such interrogations, we sketch out a recourse to the theory on the paradox of silence as it is defined by Maurice Zundel. According to him, "only silence can counterbalance the madness of men" [2]. Given that in Butterfly Burning Kwela music is connected to indigenous people's bad fate and sex regarded as an amplifier of women's minds, both musical devices and sexual practices will be highlighted as expressions and forms of silence that the Rhodesian local populations put in the limelight to egg themselves on a deadly resistance against discrimination and miserable living conditions.

\section{A Male Speaking Silence}

The missing voice of the masculine presence in Makokoba town is quite eloquent. Deprived of their humanity, men of Sidojiwe E2 road point their furrowed hopes in torn apart existences. The dryness of their ambition echoes a resignation through which their beings are crunched away and their voices pinned down into nothingness. Indeed, the prevailing colonial system does not give them a room for manœuvre to express 
their humanity. A policy of gag law tantalizes their dayto-day lives in a country whose control and economic exploitation vacuums indigenous Selfhood and Personhood:

After all, they are the ones who keep the pavements clean and sweep the entire city. They have the duty by virtue of their own [...] obedience to pick up the white men fallen on the pavements. [...]. They help these men into an upright and respectable position, then lead them into solid black cars. Then they spit on the pavement and move on" [13].

Zimbabwe becomes, in this regard, a preserve for Whites dominators who, de facto, bemused a people who's "pain knows no bounds" (p.120). Through their voicelessness, it can be read poignant historical events in the Zimbabwean past. Men's labor conditions of are reminiscent of Land 1930 Apportionment Act Britannica Encyclopedia, 2006 that officialized and institutionalized racism and separate development. In fact, colonized by the British forces, Zimbabwe in the 1930s was matched with the sharp edges of a wrought and eccentric land policy. Indeed, the range of measures that were put in practice gave shape to the land tenure Act (1969) [3] through which no individual was to be "consoled and nothing to be concealed" (p.121). Owing to such a state of depravation and thralldom, the local population moved into an élan of exclusion and powerlessness. As such, they ungraciously spurned and closed out of their own motherland. That inequity in land redistribution roused to strong feelings and actions among the dispossessed, who could not but make do with food shortage and menial works in White men's houses. To lapse such a policy, natives found strength and arm-twisting in Chimurenga liberation struggle to let their people go. Regarded as an ill-fated combat, the struggle was enacted in fire and blood. Not having wherewithal to fight themselves out of an enslaving system, indigenous populations knuckled under and bemused their revolt into silence.

In her shouldered-mission to voice out the painful segments of the Zimbabwean colonial past, Yvonne Vera puts forward a poetic description of the isotopy of silence. To this end, she gives voice to the voiceless, putting magnifying glasses on the political and social meaning of indigenous covertness. The physical exploitation they are submitted to, tells much about the colonial regime which, indeed, is on an antidemocratic showcase diet.

In point of fact, Butterfly Burning makes an open issue of men's paltry existences in colonial Zimbabwe. To keep safe and sound their own lives, anonymous laborers, who have no say on the way they are subjected to forced labor, remain, in midst of their frustration, on the sideline of silence. They are denied space for social and political articulations. And their beings are conjugated out of history. In every respect, the physical exploitation they experience in field works, is quite the only significant page open for them to write down their takings in a white dominated Rhodesia. Unnamed, they stay in a blunt anonymity with unheeded voices.

Indigenous communities suffer then from a whitish silence that finds shape into an "internal quality" [4]. The superimposed exploitation brings them into a transformational movement and turns the narrative of muteness into a reflexive actant that speaks out, noxious silence coupled with a total and absolute dispossession.

The work is not their own: it is summoned. The time is not theirs: it is seized. The ordeal is their own. They work again, and again, and in unguarded moments of hunger and surprise, they mistake their fate for fortune (p. 5).

In so being, silence becomes a voicespeaker of a day to do troubled and distressed life through which is described an expletive and "referential social malaise" [1]. The landscape of penal servitude that witnesses indigenous existential conditions is an informative unity that appears to be an expression of a "lived experience through the mediation of writing" [5]. Silence, in Butterfly Burning, is then narrativized through a descriptive text that embodies the semantic elements of enslavement and subjugation. The narrator informs in the followings:

In the air is the sound of sickle cutting grass along the roadside where black men bent their backs in the sun and hum a tune, and fume, and lullaby. They are clad in torn white shorts, short sleeves, with naked soles. The grass burns over the sickle and beyond reach over and pull at it, then curve over the sickle and beyond, pull, inward, and edge the grass forward with the left palm. They bend it toward the left shoulder and away from the eyes. Sweat drips like honey over the firm length of the arms tearing and tugging and splitting the grass. Often they manage to pull the roots out of the ground; to free something; to conquer stubbornness; to see what is below; to touch what keeps something alive and visible. Sharp rays of the sun drop along the sharp curve, and flow along the rotating glint of the silver sickle. The arm agile, the arm quick over the grass. The tall grass sweeps across the length of their curved bodies, above their bowed shoulders, and throws a cascade of already dry seeds over their bare arms. (p. 4).

Yvonne Vera has recourse to the symbolism of forced labor to underline a paradigmatic and syntagmatic relation between the isotopies of silence and that of colonization. Land dispossession in fact goes hand in glove with a verbal iron curtain among the local people. Vera exposes her citizen fellows' miserable lives, depicting silence as a sounding metaphor that looms large between the colonizer and the colonized. She metaphorizes as follows: "the voices 
of drowned men cannot be heard. The drowned die in whispers. They die in infinite solitude. The air leaves their bodies in liquid breeze." (p. 10).

To retire from time to time of the closed and mousy world, laborers call on the boons of songs. They sing their pain off and therefore relieve themselves from harassed and manhandled day by day lives. Actually, said to be created by "the children of the black slums in creative imitation of their favorite jazzmen" [6], Kwela is a musical style born around the 1950s in the South African region. In Butterfly Burning, Vera articulates the musical cord of Kwela to hint a political meaning of a people's loud and speaking silence wrought into an eerie oppression and exploitation. The natives do not find better than music to ease and nurse the pain and store away their rough anger against a repressive regime. Workers and famers find salvation in the good virtue of silenced happiness expressed through a stoic music. Silence becomes a musical rhythm and music a fulcrum for the subalterns who, indeed are defined and conjugated into an existence of "subjection and marginality" [7].

In Vera's novel, the praxis of silence is absolutely vocalized and put into a communicative process to express a framework of feeling and resentment, a sort of kinetic language through which dispossessed actors move from their status of $\mathrm{S} 1$ : subject of doing, to that of S2: subject of being. The axiom of silence bears therein the hallmarks of a logic of paradox of which political meaning slows into resignation. Unnamed farmers coalesce in a syncretism of actions, silence and rebellious resentments. Their voicelessness is then elaborated as a narrative program in which time and space spouse the values of closeness deprivation and dehumanization. As the narrator illustrates it:

Rocking and touching, each man holds on to the word the other has offered and each word raises the moment. The birth of a word, violent, mute. They are pitched against an opposite world so they plunge and pull. Each utterance is purposeful, each silence true absent desire. Impotent with unspoken words, they weave forward, and bend. They lean backward, and bend. Something burns on their lips, yes, like honey. (p. 74).

This being, anonymous workers lose their voices in a metalingus inference to operate an audible communication breakdown that is fated to be as meaningful as the audible expression. Vera's writings resonate in a breast sound that puts forward the precept of silence as an assertoric point of view that lifts a coiner of the veil to let appear the colonial cut-off points in the colonial Zimbabwean social structure. The doxa of saturnity fulfils therefore a phatic function that highlights the meaningful ground zero of communication. Through silence, Vera speaks and lets it be spoken in a form of quietus that heavily weighs on the semantic dimension of a message of reciprocal hate and rejection. Colonization is then described in Butterfly Burning as a rein through which the local populations are muzzled and exploited. And music sounds as the only magic bullet natives can make do with to express and celebrate their humanness. Vera illustrates definitely: "time has unnamed them. Placed them uniquely here. This place, this time. A buzzing like bees, but beneath the pollen, between their own feet, they make music" (p.73).

\section{When the Female Sex speaks out "the Paradox of Silence"}

"Thanks to her beauty and virtue; woman is a superior being who is in intermediary between mankind and God. The sentiment she inspires man is called love" [8]. Through these words, Genette divinizes, woman's love and makes sacrosanct her body to elevate femininity to the sheer status of Personhood and Selfhood. In Butterfly Burning, the semantic content affected to the acception of love is quite different. Indeed, torn apart by a colonial regime, Zimbabwean local people get a chip on the shoulder and find themselves obliged to bear the brunt in such a bonecrunching situation. Some women in Vera's book take it upon their sleeves to earn regular revenues for venal services.

Having left the countryside for Makokoba, the female gentry leave houses and families to venture into an unknown and unpredictable urban space. They turn their back on a tangible destitution and a striking misfortune. Actually, they join a non-rural mainstream, thinking it to mop up their suffering and cut-short their social pains. Not having pegged their dream to reality, those women, through the will of their own, recourse to prostitution to eke out a living. From the uphill of their expectations, they fall downstream of their deception. As a consequence, they find salvation in venal services they market in the streets of E2. In so doing, women embarrass the nocturnal silence to walk the night of misery and desperateness. Gertrude, whose name made of [ger] which means [spear] and [thrud] that means [strength], has a name that stands for the spear of the strength? However, she has paradoxical and ironically lost her strength and pugnacity into a life of restriction and vexation. She habours a self-concept image grounded on the dynamic structure of silence and resignation. Her 'confiscated' body by male libido is denied any access to any form of freedom of speech. In short, Gertrude's rights are silenced into nothingness and her obligations reduced to the only duty to "express the intimate truth" [9] of her being. Her ungracious fate is shared by her step daughter Phephelaphi and her friend, Zandile. The latter, who bears the brunt of a long raw to hoe, gets along in mapoto[ $\left.{ }^{1}\right]$ relationships and prostitution [10].

${ }^{1}$ Mapoto relationship is defined by Keni Benson and Joyce chadya in "Ukubhinya: gender and 
Zandille and Gertrude express the verbal language, highlighting a hostile social environment of their 'caged bodies'. They evolve in an urban milieu, in which they go through social conjunctive transformations to move into venal offers. Thus being, they identify thereby themselves as social actors fenced in a particular identity that discloses voiceless women.

Both Zandile and Gertrude are the punch bags of a colonial system that turns some black urban women into 'sexual objects' and make them bear affliction and distress in an inmost silence and a hopeless future. The narrator highlights: "Meal, there was hope. They find none. The women yank their children from the ground and proceed home, their faces turbulent, their eyes trembling. [...]They embrace an entire loss" (p. 46). Women's desire for power, their material greed and desperate need to love and beloved hustle them into the dialectic logic of Eros (love) and Thanatos (death). They are entitled to the word of silence and cannot but expose their bodies to an indicative grid of sexual services with a white policeman as a regular sexual partner.

Gertrude, at the image of the Zimbabwean land, which confiscated and exploited, is possessed and over-used by her lover. The latter, regards her as his belonging and wants her to stop welcoming other sexual partners. Emelda's not acceptance of such a deal will be the press stud that will egg the white policeman to stand at word's points and finally kill Gertrude. Female sex is then portrayed as an extension of the colonial apparatus that condemns women into abduction and silence. Women are, in Butterfly Burning, the mirror of the colonial realties based on possession and dispossession, voicelessness and unvoicelessness.

In their efforts to escape a Thanatos fate, women, in Vera's novel, tumble down in a necessity to 'cash' their bodies and truncate their freedom of speech to survive. Through that libidinal business, Vera organizes a trail of the colonial enterprise, which, indeed, subjugates women into nakedness. Marginalized and rebuked to her mindless status of a person whose first fiddle role is to welcome all due intents and purposes of a male dominating élan, Gertrude engages into a wordless resistance against the white policeman's possessive attitude. A David and Goliath issue is then raised to give form to a spectrum of an organized and organic stratification that gives no room to indigenous women.

In a tanglement of a day-to-day survival, Emelda operates a significant transformation in her

sexual violence in Bulawayo, colonial Zimbabwe 19461956 on page 112 as being a temporary male-female relationship whereby the woman would perform wifely tasks: cooking, cleaning, providing sexual services." physical contact with others. She renames herself and moves from rival and laborious to Gertrude, the spear strength. Naming, renaming and renaissance define then the limits of the "social realm" [11] to which she belongs.

In an endless quest for liberty and emancipations, women in Butterfly Burning lead hectic lives expressed in a lest writing that spouses the values of enigma and voicelesness. Through Gertrude's and Phephelaphi's destinies, Yvonne Vera pinpoints silence as one of the functional components of the female universe in colonial Zimbabwe. With a name derived from Ndebele culture and which means "where do we seek refuge", Phephelaphi is a young idling girl who moves from hand to hand seeking refuge, love and protection among individuals she thinks to be reliable. Fumbatha, the man she loves, is one of them.

Phephelaphi disadvantaged, and subdued life edges her on breaking social boundaries to nurse the ambition to go through a nursing training. Given that "education is the very essence of social change" [4], Phephelaphi rises to empower herself with a know-how so as to light her way toward emancipation. To maintain her chance to be accepted as the first black girl in the colonial nursing school, she aborts the first pregnancy she contracts with Fumbatha. This act kills the joyful side of her being and outspeaks her Selfhood oriented to self-satisfaction. As it can be read:

Phephelaphi walks in a stupor, unable to bury her pain; not clear if she has parted from death or life. Folded into two halves, one part of her is dead, the other is living. Not knowing which stronger ( $p$. $127)$ is.

Phephelaphi prefers an emancipating training to a disqualifying pregnancy. The Self takes over to the Selves and pins down a male expression upon the female being. In her quest to unburden herself of the patriarchal yoke and the colonial serfdom, Fumbatha's girlfriend achieves a dramatic act which finds expression in the borderline of criminality. She imposes upon herself the fatality of silence. And life becomes a matter of choice that, whatever can be the result, goes with secrecy and muteness. To say on this, the narrator furthers the point: "O song lights her lips, but she has no words for it. She tries again. No words, just the shape, a frantic belle salt over her tongue" (pp. 127 128).

In challenging her society's norms and rules, 'the one who seeks refuge' finds all wayouts stonewalled. Fambutha, the man on whom Phephelaphi can rely, withdraws his confidence from her and the moral support he is supposed to provide to a partner in disarray:

An obstacle whichever direction her mind opens. Something else lager and solid, has cast a terrible 
shadow into her being, split her mind into irreconcilable parts, breaks her fragments. Has swallowed every other detail, her lonesome search, and she wonders therefore, why she still fails to close her eyes and sleep, and forget the fine dust sucking at her throat, hindering her ( $\mathrm{p}$. 128).

Between Gertrude daughter and Fumbatha settles down a love-and-hate relation. They love each other, but deeply divided in terms of ambition and objectives. Phephelapi assertively aborts to join action in nursing training, while Fumbatha remains stuck to a male-oriented attitude that always targets to cage women at home for wifely duties. Cornered in a world of silence and deadlocks that find ground in the claws of tradition and shackles of colonization, Phephelaphi takes a radical and definite solution to sort out the problematic equation of her double-sided life. She commits a suicide and silences herself through time and space.

From cradle to grave, her existence rhythms the whims of a bad-defined destiny that stresses on the double-edged extreme injustice and that seems to be hereditary for women in a white dominated Rhodesia.

\section{CONCLUSION}

The theme related to the corporeality silence is highly structured and variously articulated in Yvonne Vera's Butterfly Burning, in which the author has efficiently unhookd men's and women's stiffened blubbers in a context of colonial dominations. Indeed, men overexploitation in field works speaks loud the silence of misery and dehumanization they are victim of. The silence of word and the words of silence weave back and forth to write out the discourse of a rejected domination. Vera shushes a pencil between lines to set down the caricature of an apartheid system that imposes a psychological and moral violence upon indigenous populations.

In her capacity as a female voice, Vera has dropped a line on the female fated existence in colonial Rhodesia. She has given a ring on the sexual demission of women's canvass of expression. Sex and sexuality form flowers of evil that instill deathly silence upon the 'weak' sex in Zimbabwe. Vera then touches, with an accusing finger, the wrongness of an unfair system through which the natives are dispossessed of their independence and dehumanized beyond recognition. She points out sex as a consolatory statement in an urban space where a "male superordination and female subordination" are highlighted [12]. Men and women indeed, are tormented through a paradox of silence and jolted in a harassing dilemma they, in a way or another, express in a convent society. Thus being so, she notes down, to put all interested in the know, the female promiscuity that hinders women's emancipation.
Field works are the exhausting activities that bemuse and bereave black native laborers who toil and moil in a land that does not belong to them anymore. Dominated and daily hassled by colonial compradors, men and women voice their submissiveness in highspeaking silence. Vera exposes their bodies to get tem express a long-lasting desperation through which they are identified as pinned down labor-forces which cannot neither assess Personhood nor full Selfhood.

Besides, music is then described by Yvonne Vera as the only external voice that cradles away men's and women's fatigue, and hopelessness [13]. Vera rhythms then Kwela music to make vibrate the cords of anxiousness of people who speak through a meaningful silence.

\section{REFERENCES}

1. Sene, A. (2015). Sémiotique de l'espace et sémantique du discours littéraire dans les oeuvres de Ngugi wa Thiong'o, George Lamming et William Boyd. Édilivre.

2. Zundel, M. (2000). A L'écoute du silence. Paris: Téqui.

3. Hill, R., \& Katarere, Y. (2002). Colonialism and inequity in Zimbabwe. Matthew, Richard, Mark Halle \& Jason Switzer: Conserving the Peace: Resources, Livelihoods, and Security, IISD/IUCN, 247-271.

4. Lunyne, W. (1990). Approche sémiotique de Maurice Blanchot. Paris: L'harmattan, 1990.

5. Duchet, C. (1997). L'étude sociocritique. Paris: Seuil, 1997.

6. Allen, L. V. (1993). Pennywhistle kwela: a musical, historical and socio-political analysis (Doctoral dissertation).

7. Nwakanma, O. (2013). The Nation and the Subaltern in Yvonne Vera's Butterfly Burning. Tydskrif vir letterkunde, 50(1), 36-46.

8. Gérard, G. E. N. E. T. T. E. (1966). Figure I. Paris: Éditions du Seuil, coll.,, Tel Quel, 60-69.

9. Miraux, J. P. (2009). L'autobiographie: écriture de soi et sincérité. Armand colin.

10. Benson, K., \& Chadya, J. (2003). Ukubhinya: Gender and Sexual Violence in Bulawayo, Colonial Zimbabwe, 1946-1956. Zambezia, 30(1), 108-133.

11. SANÉ, A. M. (2017). The novel, the individual and the community: towards an african reception of george eliot's. Partage du savoir-Mélanges offerts en hommage au Professeur Mamadou Kandji: Tome 1, Littérature, 2, 303.

12. Sadek, S. (2014). The struggle of African women in selected works by Ngugi Wa Thiongo. European Scientific Journal, 10(5).

13. Vera, Y. (2000). Butterfly Burning: A Novel. Macmillan. 